\title{
PENGEMBANGAN BOOKLET BERBASIS KEARIFAN LOKAL PADA MATERI TUMBUHAN (PLANTAE) KELAS X MIPA MAN 1 (MODEL) LUBUKLINGGAU
}

\author{
Rina Melati ${ }^{1}$, Mareta Widiya ${ }^{1 *}$, Linna Fitriani ${ }^{1,}$ Poppy Antika Sari ${ }^{2}$ \\ ${ }^{1}$ Program Studi Pendidikan Biologi, STKIP PGRI Lubuklinggau \\ ${ }^{2}$ Program Studi Tadris IPA, IAIN Bengkulu \\ e-mail: maretawidiya@gmail.com
}

\begin{abstract}
Abstrak
Penelitian ini bertujuan untuk mengetahui hasil pengembangan booklet berbasis kearifan lokal pada materi tumbuhan (Plantae). Instrumen pengumpulan data yang digunakan adalah lembar validasi, angket, lembar tes, dan lembar wawancara. Produk penelitian ini berupa booklet siswa berbasis kearifan lokal pada materi tumbuhan (Plantae) kelas X MIPA. Hasil penelitian menunjukkan bahwa: (1) kualitas booklet dilihat dari aspek kevalidan termasuk dalam kategori valid dengan skor rata-rata 3,39; (2) kualitas booklet dilihat dari aspek kepraktisan dikategorikan sangat praktis dengan skor rata-rata 3,56; dan (3) booklet memiliki efek (keefektifan) terhadap hasil belajar siswa dimana 34 siswa $(87,2 \%)$ di kategorikan tuntas sedangkan ada 5 siswa $(12,8 \%)$ belum tuntas dengan Ketuntasan Belajar Minimal (KBM) yang ditetapkan sekolah minimal siswa mendapat nilai 75. Kesimpulan penelitian ini yaitu booklet yang dikembangkan dapat dijadikan salah satu alternatif media pembelajaran biologi siswa kelas X MIPA MAN 1 (Model) Lubuklinggau dan guru biologi pada materi tumbuhan (Plantae).
\end{abstract}

Keywords: Booklet , Kearifan lokal, Tumbuhan (Plantae)

\begin{abstract}
This research aimed to knew the development of local wisdom-based booklets on plant matter (Plantae). The data collection instruments used were validation sheets, questionnaires, test sheets, and interview sheets. The product of this research was in the form of student booklet based on local wisdom on plant material (Plantae) class X MIPA. The results showed that: (1) the quality of the booklet, seen from the validity aspect, was included in the valid category with an average score of 3.39 ; (2) the quality of the booklet, seen from the practicality aspect, was categorized as very practical with an average score of 3.56; and (3) the booklet has an effect (effectiveness) on student learning outcomes where 34 students $(87.2 \%)$ are categorized as complete while there are 5 students $(12.8 \%)$ who have not completed with minimal learning completeness (KBM) determined by the minimum school of students. got a score of 75 . The conclusion in this study is that the developed booklet can be used as an alternative learning media for biology learning media for students of class X MIPA MAN 1 (Model) Lubuklinggau and biology teachers on plant material (Plantae).
\end{abstract}

Keywords: Booklet , Local Wisdom, Plant (Plantae).

\section{PENDAHULUAN}

Pendidikan yang berkualitas sangat ditentukan oleh teknik pengajaran yang dilakukan oleh guru (Boleng et al., 2017). Guru wajib memperhatikan kebutuhan setiap siswa dalam kegiatan belajar (Averos et al., 2019). Pengajaran yang sebagian besar berpusat pada guru seringkali gagal membentuk kompetensi siswa (Gregor, 2012). United Nations Educational, Scientific and Cultural Organization (UNESCO), telah mengidentifikasi ada beberapa aspek yang mendukung pendidikan yang berkualitas dan bisa disesuaikan dengan cara belajar setiap individu dan sistem pendidikan yang ada suatu negara. Seperti aspek pada konten 
isi pembelajaran, pengalaman belajar, menggunakan cara belajar yang bervariasi, dan salah satunya adalah meningkatkan lingkungan belajar yang dinamis, sehingga bisa dikembangkan kemampuan berpikir kritis setiap siswa (Lee, 2010).

Perkembangan sains pada abad 21 saat ini sangat menuntut pengajar untuk bisa memotivasi kemampuan berpikir tiap siswa (Permana et al., 2019). Kemampuan berpikir kritis setiap siswa dalam mata pelajaran biologi sangat diperlukan (Changwong et al., 2018), Siswa dapat secara aktif dan terampil dalam menemukan konsep, menerapkan, menganalisis, mensintesis, dan mengevaluasi informasi untuk mencapai sebuah kesimpulan dari suatu konsep.

Keterampilan berpikir kritis dalam kegiatan pembelajaran sangat berpusat pada siswa. Akan tetapi, peran guru juga tidak kalah penting dalam kegiatan pembelajaran. Karena dalam proses pembelajaran terjadi interaksi antara guru dengan siswa (Puspita et al., 2017). Dalam melaksanakan tugas profesionalnya, guru juga terlibat langsung dalam pembentukan dan pengembangan intelektual dan kepribadian siswa, untuk itu guru harus memiliki keterampilan dan kemampuan mengelola kegiatan belajar siswa (Mahanal et al., 2019).

Hasil observasi pembelajaran di MAN 1 Model Lubuklinggau, diketahui bahwa bahan ajar yang tersedia di sekolah berupa buku cetak dan lembar kerja siswa. Sebagian guru hanya tergantung pada bahan ajar yang sudah tersedia di sekolah, tanpa melakukan inovasi dan pengembangan terbaru terhadap bahan ajar yang ada, sehingga kegiatan belajar mengajar menjadi kurang menarik minat siswa.
Pada proses pembelajaran berlangsung siswa lebih cenderung pasif, kegiatan belajar lebih banyak menyimak penyampaian materi oleh guru, hanya ada beberapa siswa yang mau bertanya dan menyampaikan pendapatnya. Kegiatan pembelajaran tersebut kurang sesuai dengan konsep penerapan Kurikulum 2013 (K.13). Aktivitas belajar K.13 lebih menekankan pada pembelajaran saintifik, seperti berfikir ilmiah, berinovasi, berfikir kritis dan memecahkan masalah (Mahanal et al., 2019). Guru wajib menciptakan pembelajaran yang berinovasi, berpusat pada siswa dan menggunakan sumber dan media pembelajaran yang relevan dengan materi ajar (Yani et al., 2018).

Informasi dari Guru Biologi di MAN 1 Model Lubuklinggau, materi biologi yang dirasakan masih sulit penerapannya adalah pada materi tumbuhan (Plantae). Karena keanekaragaman spesies tumbuhan (Plantae) merupakan materi yang objek belajarnya sangat luas. Dengan demikian perlu dikembangkan media booklet berbasis kearifan lokal pada materi Plantae yang dapat menjadi panduan siswa untuk belajar dan mendekatkan siswa kepada alam. (Puspita et al., 2017), booklet adalah media untuk meningkatkan minat dan hasil belajar siswa serta sumber belajar alternatif bagi siswa yang bisa menambah pengetahuan semakin luas serta praktis penggunaanya. (Ridlo et al., 2013), Pemanfaatan potensi lokal yang dijadikan sumber belajar Biologi merupakan salah satu karakteristik yang diharapkan dituntut oleh kurikulum agar pembelajaran lebih aplikatif dan bermakna. 


\section{METODE}

\section{a. Jenis Penelitian}

Jenis penelitian ini yaitu penelitian pengembangan atau Research and Development (R\&D).

\section{b. Prosedur Pengembangan}

Prosedur pengembangan dalam penelitian ini yaitu:

\section{Tahap Pendefinisian (define)}

Tahap ini meliputi 5 langkah pokok, yaitu analisis awal-akhir, analisis siswa, analisis konsep, analisis tugas, perumusan atau spesifikasi tujuan.

\section{Tahap Perencanaan (Design)}

Tujuan tahap perencanaan adalah untuk merancang penyusunan tes, penyusunan media, pemilihan format dan rancangan awal.

\section{Tahap Pengembangan (Develop)}

Tahap pengembangan adalah bentuk akhir media pembelajaran setelah dilakukan revisi berdasarkan masukkan dari para ahli dan data hasil uji coba terbatas. Dari hasil penilaian validator diperoleh koreksi, kritik, dan saran. Kevalidan produk yang diciptakan akan terlihat dari uji validasi yang divalidasi oleh ahli tiap bidangnya. Keefektifan produk yang diciptakan akan terlihat dari hasil nilai tes soal yang didapat pada hasil belajar siswa. Sedangkan kepraktisan produk yang diciptakan akan terlihat dari lembar angket respon siswa.

\section{c. Subjek penelitian}

Subjek dalam penelitian yaitu siswa kelas X MAN 1 Model Lubuklinggau.

\section{d. Alat Pengumpulan Data}

Teknik pengumpulan data yang digunakan yaitu, lembar observasi, angket, lembar wawancara dan tes.

\section{Observasi}

Mulyatiningsih (2014), observasi adalah pengumpulan data melalui pengamatan dan pencatatan perilaku subjek penelitian yang dilakukan secara sistematik.

\section{Angket}

Angket merupakan alat pengumpulan data yang memuat sejumlah pertanyaan atau pernyataan yang harus dijawab oleh subjek penelitian (Setyaningsih et al., 2019). Ada 2 macam angket yang digunakan, yaitu angket untuk validator ahli dan angket untuk siswa kelas X MIPA MAN 1 Model Lubuklinggau.

\section{Wawancara}

Wawancara yaitu menemukan informasi dengan memberikan pertanyaan pada responden secara tatap muka (Muhammad \& Kabir, 2018). Wawancara dilakukan dengan guru mata pelajaran Biologi MAN 1 Model Lubuklinggau.

\section{Tes}

Tes diperlukan untuk mengetahui kelayakan Booklet ditinjau dari aspek keefektifan. Data hasil tes berupa data kuantitatif/angka.

\section{e. Teknik Analisis Data}

Pengolahan data dalam penelitian ini dilakukan dengan menggunakan analisis deskriptif kuantitatif. Tahapan analisis data yang digunakan yaitu :

\section{Analisis Kevalidan}

Analisis kevalidan digunakan untuk menentukan kevalidan booklet berbasis kearifan lokal yang dikembangkan. Lembar validasi ini dibedakan menjadi tiga, yaitu untuk validator materi, validator bahasa dan validator media yang masing-masing terdiri dari butirbutir pertanyaan.

a) Hasil validasi yang diperoleh kemudian dianalisis dengan penskoran angket. Nilai sangat baik (4), baik (3), tidak baik (2) dan sangat tidak baik (1).

b) Mengubah skor rata-rata seluruh aspek menjadi nilai kualitatif sesuai 
dengan pedoman konversi pada Tabel 1 berikut:

Tabel 1. Pedoman Konversi Rata-rata Skor Validasi

\begin{tabular}{ll}
\hline Nilai & Kategori \\
\hline$X>M i+1,8 S b i$ & Sangat valid \\
$M i+0,6 S b i<X \leq M i+1,8 S b i$ & Valid \\
$M i-0,6 S b i<X \leq M i+0,6 S b i$ & Cukup valid \\
$M i-1,8 S b i<X \leq M i-0,6 S b i$ & Kurang valid \\
$X \leq M i-1,8 S b i$ & Tidak valid \\
\hline
\end{tabular}

Keterangan:

$M i=\frac{1}{2}$ (skor maksimal idel + skor minimal ideal)

$S b i=\frac{1}{6}$ (skor maksimal idel - skor minimal ideal)

$X=$ rata-rata total skor

\section{Analisis Keefektifan}

Analisis keefektifan booklet dikembangkan melalui data pengukuran hasil belajar siswa. Data dari hasil pengerjaan soal tersebut dianalisis dengan langkah-langkah sebagai berikut.

a. Menghitung skor yang diperoleh siswa menggunakan pedoman penskoran tes hasil belajar.

b. Menentukan nilai akhir yang didapat siswa menggunakan rumus berikut:

Nilai akhir $=\frac{\text { skor yang didapat }}{\text { skor maksimal }} x 100 \%$

c. Menghitung banyaknya siswa yang tuntas atau mencapai Ketuntasan Belajar Minimal (KBM) yang telah ditetapkan sekolah yaitu 75 .

Persentase ketuntasan tersebut menjadi nilai kualitatif sesuai dengan Tabel 2 berikut:
Tabel 2. Kategori Persentase Ketuntasan Klasikal

\begin{tabular}{ll}
\hline Interval (\%) & Kategori \\
\hline$P \geq 90$ & Sangat baik \\
$80 \leq P<90$ & Baik \\
$70 \leq P<80$ & Cukup baik \\
$60 \leq P<70$ & Kurang baik \\
$P<60$ & Tidak baik \\
\hline
\end{tabular}

Booklet dikatakan layak ditinjau dari aspek keefektifan apabila persentase ketuntasan klasikal pada $P \geq 80 \%$.

\section{Analisis Kepraktisan}

Analisis angket kepraktisan digunakan untuk menentukan kepraktisan produk booklet. Analisis data angket kepraktisan dianalisis menggunakan skala likert yaitu seperti pada Tabel 3. Pedoman penilaian angket dan kemudian dikonversi sesuai Tabel 3.

Tabel 3. Pedoman Penilaian Angket

\begin{tabular}{ll}
\hline Nilai & Pernyataan \\
\hline 4 & Sangat Baik \\
3 & Baik \\
2 & Tidak baik \\
1 & Sangat tidak baik \\
\hline
\end{tabular}

\section{HASIL DAN PEMBAHASAN}

Hasil analisis penilaian kevalidan booklet dari empat pakar ahli yaitu ahli media, ahli materi, ahli bahasa dan ahli praktisi lapangan terhadap booklet berbasis kearifan lokal terlihat dalam Tabel 4.

Tabel 4. Rekapitulasi Hasil Penilaian Para Ahli

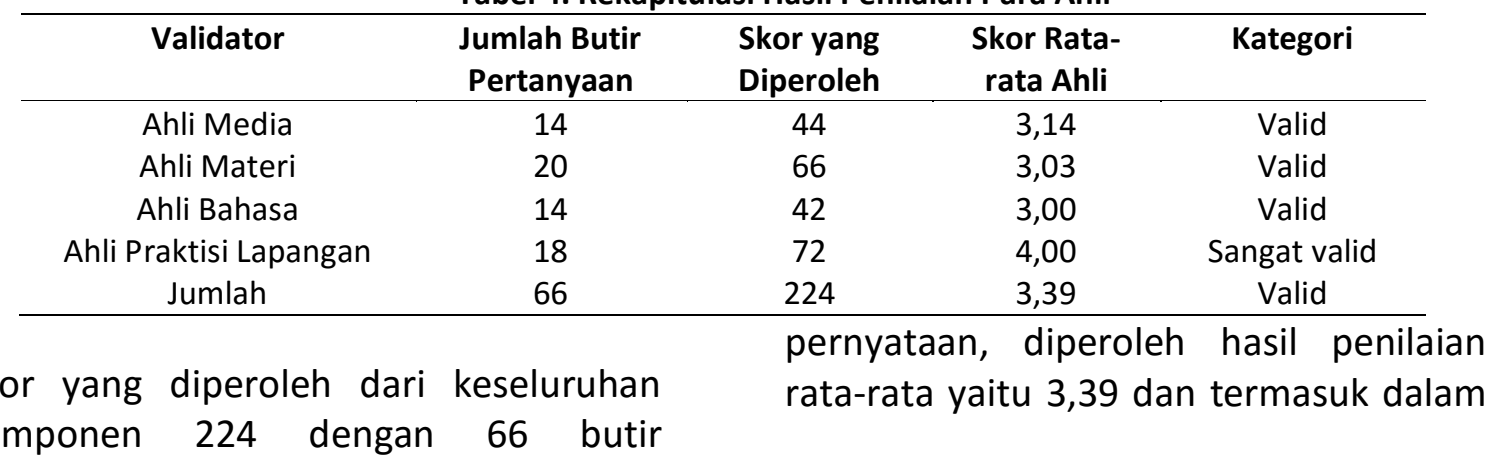


kategori valid. Kualitas booklet dilakukan uji validasi dikarenakan kualitas penelitian bisa diketahui ketelitian, dan dapat dimanfaatkan dalam praktiknya nanti dan harapan akhirnya bisa membantu kualitas materi pendidikan di masa mendatang (Farizan et al., 2020). Data hasil analisis angket kepraktisan dapat dilihat pada Tabel 5.

Tabel 5. Hasil Analisis Angket Kepraktisan

\begin{tabular}{|c|c|c|c|}
\hline No & Pernyataan & $\mathbf{N}$ & $\begin{array}{l}\text { Skor Yang } \\
\text { Diperoleh }\end{array}$ \\
\hline 1 & Materi yang disajikan dapat dipahami & 39 & 141 \\
\hline 2 & $\begin{array}{l}\text { Isi/materi dalam booklet dapat menambah pengetahuan, } \\
\text { pemahaman serta wawasan tentang keanekaragaman hayati }\end{array}$ & 39 & 139 \\
\hline 3 & $\begin{array}{l}\text { Booklet dalam materi tumbuhan (Plantae) disajikan secara } \\
\text { lengkap sehingga dapat membantu pembelajaran dikelas }\end{array}$ & 39 & 140 \\
\hline 4 & $\begin{array}{l}\text { Booklet bermanfaat dalam membantu belajar selain buku paket } \\
\text { dan LKS }\end{array}$ & 39 & 137 \\
\hline 5 & $\begin{array}{l}\text { Materi yang disajikan dengan bahasa yang sederhana sehingga } \\
\text { mudah dipahami }\end{array}$ & 39 & 148 \\
\hline 6 & $\begin{array}{l}\text { Gambar dan ilustrasi yang disajikan didalam Booklet menarik } \\
\text { dan sesuai dengan materi tumbuhan (Plantae) }\end{array}$ & 39 & 145 \\
\hline 7 & Terdapat penjelasan untuk istilah yang sulit dan tidak umum & 39 & 134 \\
\hline 8 & $\begin{array}{l}\text { Bahasa yang digunakan dalam booklet komunikatif sehingga } \\
\text { mudah dimengerti }\end{array}$ & 39 & 137 \\
\hline 9 & Desain sampul, gambar, dan tulisan menarik & 39 & 137 \\
\hline 10 & Layout pada booklet proposional sehingga menarik untuk dibaca & 39 & 134 \\
\hline 11 & $\begin{array}{l}\text { Tampilan tiap halaman menarik perhatian untuk mempelajari } \\
\text { materi tumbuhan (Plantae) }\end{array}$ & 39 & 132 \\
\hline 12 & Booklet sangat simpel untuk dibawa dan dipelajari & 39 & 142 \\
\hline 13 & $\begin{array}{l}\text { Keseimbangan gambar dan teks menarik dan tidak } \\
\text { membosankan untuk dibaca }\end{array}$ & 39 & 137 \\
\hline 14 & $\begin{array}{l}\text { Tampilan keseluruhan booklet menarik dan dapat menambah } \\
\text { minat baca }\end{array}$ & 39 & 144 \\
\hline \multicolumn{2}{|c|}{ Jumlah } & 546 & 1947 \\
\hline \multicolumn{2}{|c|}{ Skor Rata-Rata } & 3,56 & \\
\hline \multicolumn{2}{|c|}{ Kategori } & Sang & \\
\hline
\end{tabular}

Hasil analisis data angket dari kepraktisan yang diberikan kepada siswa kelas $X$ MIPA 4 MAN 1 Model Lubuklinggau yang berjumlah 39 siswa dikalikan 14 butir pernyataan dan memiliki jumlah skor keseluruhan 1947, Sehingga skor rata-rata yang diperoleh adalah 3,56. Dengan demikian hasil penilaian angket kepraktisan terhadap booklet yang dikembangkan dikategorikan sangat praktis. Analisis hasil belajar siswa untuk mengetahui keefektifan booklet berbasis kearifan lokal yang dikembangkan dapat dilihat pada Tabel 6.

Tabel 6. Hasil Analisis Data Hasil Belajar Siswa

\begin{tabular}{cccc}
\hline Rentang Nilai & Jumlah Siswa & Persentase (\%) & Kategori \\
\hline $96-100$ & 6 & $15,4 \%$ & Tuntas \\
$86-95$ & 15 & $38,4 \%$ & Tuntas
\end{tabular}




\begin{tabular}{cccc}
\hline $76-85$ & 13 & $33,4 \%$ & Tuntas \\
$<75$ & 5 & $12,8 \%$ & Tidak Tuntas \\
\hline
\end{tabular}

Booklet berbasis kearifan lokal, dimana media ini disusun berdasarkan kebutuhan guru dan siswa kelas X MIPA MAN 1 Model Lubuklinggau. Proses pengembangan booklet berbasis kearifan lokal pada materi Plantae menggunakan model pengembangan 4-D modifikasi Thiagarajan yaitu terdiri dari empat tahap berupa pendefinisian (define), perancangan (design), pengembangan (develop), dan penyebaran (dessiminate).

Komponen booklet dilihat dari komponen desain dan tampilan fisik, cakupan materi, keakuratan materi, kemutakhiran materi, wawasan, kesesuaian dengan perkembangan siswa, kesesuaian dengan kaidah bahasa Indonesia yang benar, penggunaan istilah, keterbacaan, kriteria penulisan, tujuan penyajian dan pembelajaran, serta aspek pembelajaran berbasis kearifan lokal.

Uji coba yang dilakukan oleh peneliti melalui 3 tahapan yaitu uji coba peorangan yang dilakukan oleh 6 siswa. Hasil dari uji coba perorangan mendapatkan skor rata-rata 3,27 dengan kategori praktis, sehingga booklet bisa diujicobakan pada tahap selanjutnya. Tahap kedua yaitu booklet diujicobakan kembali pada kelompok kecil yang terdiri dari 6 siswa yang memiliki kemampuan sedang, rendah dan tinggi untuk mengetahui respon siswa terhadap booklet. Uji coba kelompok kecil mendapatkan respon positif dari siswa dengan mendapatkan skor rata-rata 3,55 dengan kategori sangat praktis, sehingga booklet bisa diujicobakan pada tahap ke tiga yaitu uji coba kelompok besar yang dilakukan di MAN 1 Model Lubuklinggau dengan melibatkan 39 siswa kelas $X$
MIPA 4. Uji coba kelompok besar mendapatkan skor rata-rata 3,56 dengan kategori sangat praktis.

Booklet yang dikembangkan memiliki keefektifan melebihi 80\%. 34 siswa atau sekitar $87,2 \%$ telah tuntas dengan kategori baik sedangkan ada 5 siswa atau sekitar 2,8\% belum tuntas. Hasil pelaksanaan tes tersebut diperoleh bahwa rata-rata hasil belajar siswa, nilainya berada diatas KBM. Mengindikasikan bahwa siswa mampu menyerap pelajaran dan menambah pengetahuannya dengan menggunakan media pembelajaran yang dikembangkan. Menurut Kamaludin et al (2018) penggunaan bahan ajar dapat membantu meningkatan hasil belajar siswa dalam memecahkan masalah. Peningkatan hasil belajar yang baik ini terkait dengan karena pola pembelajaran siswa yang berbasis kearifan lokal dan alami. Karena Biologi adalah salah satu bidang pelajaran yang sangat erat kaitannya makhluk hidup sekitarnya. Sehingga menyebabkan ada interaksi antar siswa, siswa dengan guru dan siswa dengan keadaan lingkungan (Sulaiman et al., 2018).

Selain berpatokan dengan penilaian hasil belajar siswa dan angket kepraktisan siswa, tingkat keefektifan media pembelajaran dapat dilihat dari respon siswa terhadap penggunaan media selama proses pembelajaran berlangsung. Selama proses pembelajaran, siswa berantusias untuk belajar yang ditandai dengan siswa aktif bertanya dan berdiskusi dengan guru dan teman kelasnya. Hal ini dikarenakan media pembelajaran yang digunakan cukup menarik, menambah wawasan, dan pengetahuan, karena pada media 
dicantumkan spesies-spesies yang ada di lingkungan sekitar yang sering dijumpai siswa dalam kehidupan sehari-harinya.

Penggunaan booklet mendukung hasil belajar siswa pada ranah afektif lebih banyak menciptakan rasa ingin tahu, saling menghargai, berkolaborasi di dalam kelompok (memberikan pendapat) serta rasa tanggung jawab (Rani et al., 2020). Media pembelajaran booklet ini sangat penting bagi motivasi siswa. Menurut Junaidi (2019) media pembelajaran mempengaruhi motivasi, minat, dan lingkungan belajar. Peningkatan interaksi antara pembelajar dengan pebelajar, dapat menciptakan suasana proses pembelajaran menjadi lebih efektif dan efisien (Junaidi, 2019).

Media pembelajaran dalam bentuk booklet memiliki corak gambar yang berwarna dan simple (mudah dibawa), tentu berbeda dengan buku yang penuh dengan deretan kecil-kecil dan dipenuhi dengan kata-kata yang panjang (Fitriasih et al., 2019). Pembelajaran dengan memanfaatkan keadaan lingkungan juga dapat memberikan stimulasi dan inspirasi pembelajaran yang bermakna (Mirrahimi et al., 2011).

Faktor penting yang
mempengaruhi kegiatan pembelajaran adalah guru profesional dalam menggunakan berbagai metode pengajaran yang beragam, karena tidak ada jaminan pendekatan pengajaran khusus akan memberikan hasil yang diinginkan bagi siswa (Siegert et al., 2017).

\section{PENUTUP}

\section{Simpulan}

Media pembelajaran booklet berbasis kearifan lokal dikembangkan dengan model pengembangan 4-D dan hanya menggunakan 3 tahap diantaranya: (1) define, (2) design, dan (3) develop. Analisis kevalidan booklet dikategorikan "Valid" dengan skor ratarata 3,39. Kepraktisan booklet siswa menunjukkan rata-rata skor sebesar 3,56 termasuk dalam kategori "sangat praktis". Dari nilai keefektifan terhadap hasil belajar siswa X MIPA MAN 1 Model Lubuklinggau, dari 34 siswa $(87,2 \%)$ telah tuntas dengan kategori baik, sedangkan ada 5 siswa $(12,8 \%)$ belum tuntas.

\section{Saran}

Saran dari penelitian ini adalah sebaiknya dapat membuat variasi booklet dalam mata pelajaran biologi untuk sub-bab materi lainnya. Dalam penerapan pembelajaran sangat diharapkan untuk ujicoba kelompok besar lagi dengan dipadukan model Project Based Learning (PjBL).

\section{DAFTAR PUSTAKA}

Averos, I. F., Widiyatami, C. A., Esti, W., \& Utami, T. (2019). Diversity of Ferns (Pteridophyta) in Ancient Volcano Mount Nglanggeran Climbing Track and the Booklet Development for Independent Learning Sources. 2, 101-105.

Boleng, D. T., Lumowa, S. V. T., Palenewen, E., \& Corebima, A. D. (2017). The effect of learning models on biology critical thinking skills of multiethnic students at senior high schools in Indonesia. Problems of Education in the 21st Century, 75(2), 136-143.

Changwong, K., Sukkamart, A., \& Sisan, B. (2018). Critical thinking skill development: Analysis of a new learning management model for Thai high schools. Journal of International Studies, 11(2), 37-48. 
https://doi.org/10.14254/20718330.2018/11-2/3.

Farizan, N. H., Sutan, R., Hod, R., \& KC Mani, K. (2020). Development and validation of a health educational booklet: A parent's role in water safety and drowning prevention. Journal of Health Research, 34(3), 233-246.

https://doi.org/10.1108/JHR-052019-0101.

Fitriasih, R., Kasrina, I., \& Kasrina, K. (2019). Pengembangan Booklet Keanekaragaman Pteridophyta Di Kawasan Suban Air Panas Untuk Siswa Sma. Diklabio: Jurnal Pendidikan Dan Pembelajaran Biologi, 3(1), 100-108. https://doi.org/10.33369/diklabio.3. 1.100-108.

Gregor, H. E. M. (2012). Decolonizing Pedagogies Teacher Reference Booklet. In Decolonizing Pedagogies Teacher Reference Booklet (Issue March, pp. 1-15). Aboriginal Focus School, Vancouver School Board Introduction.

Junaidi, J. (2019). Peran Media Pembelajaran Dalam Proses Belajar Mengajar. Diklat Review: Jurnal Manajemen Pendidikan Dan Pelatihan, 3(1), 45-56. https://doi.org/10.35446/diklatrevi ew.v3i1.349.

Kamaludin, S., Surtikanti, H. K., Surakusumah, W., Education, B., Program, S., Sciences, E. N., \& Java, W. (2018). Developing Issue-Based Teaching Materials to Improve Student Learning Outcomes in
Freshwater Biology Course. 4(2), 161-170. Diakses: 11 September 2020

Lee, J. C. K. (2010). Education for sustainable development in China. In Chinese Education and Society (Vol. 43, Issue 2). https://doi.org/10.2753/CED10611932430207. Diakses: 2 November 2020

Mahanal, S., Tendrita, M., Ramadhan, F., Ismirawati, N., \& Zubaidah, S. (2019). The Analysis of Students' Critical Thinking Skills on Biology Subject. Anatolian Journal of Education, 2(2). https://doi.org/10.29333/aje.2017. 223a. Diakses: 10 September 2020 Mirrahimi, S., Tawil, N. M., Abdullah, N. A. G., Surat, M., \& Usman, I. M. S. (2011). Developing Conducive Sustainable Outdoor Learning: The Impact of Natural environment on Learning , Social and Emotional Intelligence. Procedia Engineering, 20, 389-396. https://doi.org/10.1016/j.proeng.20 11.11.181. Diakses: 09 September 2020

Muhammad, S., \& Kabir, S. (2018). Methods of data collection. July 2016.

Permana, T. I., Hindun, I., Rofi'ah, N. L., \& Azizah, A. S. N. (2019). Critical thinking skills: The academic ability, mastering concepts and analytical skill of undergraduate students. Jurnal Pendidikan Biologi Indonesia, 5(1), 1-8. https://doi.org/10.22219/jpbi.v5i1.7 626. Diakses: 10 September 2020

Puspita, A., Kurniawan, A. D., \& Rahayu, H. M. (2017). Pengembangan Media Pembelajaran Booklet Pada Materi Sistem Imun Terhadap Hasil Belajar Siswa Kelas Xi Sman 8 Pontianak. 
Jurnal Bioeducation, 4(1), 64-73. https://doi.org/10.29406/524.

Rani, B. K., Widiyaningrum, P., \& Anggraito, Y. U. (2020). Journal of Innovative Science Education Effectiveness of Research Based Booklet Media of Conventional Biotechnology Application As A Supplement of Biotechnology Teaching Materials in Senior High School. 9(3), 5-10.

Ridlo, S., Semarang, U. N., Alimah, S., \& Semarang, U. N. (2013). Biosaintifika. October 2016. https://doi.org/10.15294/biosaintifi ka.v5i2.2752.

Setyaningsih, E., Sunandar, A., \& Setiadi, A. E. (2019). Pengembangan Media Booklet Berbasis Potensi Lokal Kalimantan Barat Pada Materi Keanekaragaman Hayati Pada Siswa Kelas $X$ di SMA Muhammadiyah 1 Pontianak. Pedagogi Hayati, 3(1), 44-52.

https://doi.org/10.31629/ph.v3i1.1 068.

Siegert, J., Schlegel, T., Groß, E., \& Bauernhansl, T. (2017). Standardized Coordinate System for Factory and Production Planning. Procedia Manufacturing, 9, 127134.

https://doi.org/10.1016/j.promfg.20 17.04.032.

Sulaiman, M., Ngabekti, S., \& Widiatningrum, T. (2018). The Development of Booklet about the Variety of Macroscopic Fungi Species in Arboretum Sylva Western Borneo as the Supplement of Learning Material at High School.
Jise, 7(2), 343-351.

Yani, A., Sahriah, S., \& Haerunnisa, H. (2018). Efektivitas Pendekatan Saintifik Dengan Media Booklet Higher Order Thinking Terhadap Hasil Belajar Biologi Siswa Sma Di Kabupaten Wajo. Biosel: Biology Science and Education, 7(1), 1. https://doi.org/10.33477/bs.v7i1.38 7. 